\title{
MODEL JARINGAN SYARAF TIRUAN DALAM MEMPREDIKSI PENDAPATAN PERKAPITA MASYARAKAT PERKOTAAN PADA GARIS KEMISKINAN BERDASARKAN PROPINSI
}

\author{
${ }^{1}$ Ahmad Revi, ${ }^{2}$ Syahrul Ramadan, ${ }^{3}$ Rina Novita Sari, ${ }^{4}$ Solikhun \\ 1,2,3,4Program Studi Manajemen Informatika, AMIK Tunas Bangsa Pematangsiantar \\ Jln. Jenderal Sudirman Blok A No. 1,2,3 Pematangsiantar \\ ahmadrevi98@gmail.com, syahrul.ramadan208@gmail.com, \\ rinanovitasari538@gmail.com, solikhun@amiktunasbangsa.ac.id
}

\begin{abstract}
The problem of poverty is one of the fundamental issues that becomes the center of attention of the Government in any country. In an effort to realize the provisions as stipulated in Article 28A of the 1945 Constitution of the State of the Republic of Indonesia which affirms that every person has the right to live and has the right to maintain his life and life, the GOI has established a poverty reduction program as a priority program. The primary target of poverty is mostly in urban areas, because the large number of residents who do transmigration to improve the economy but failed to get results. This study contributes to the government to predict the per capita opinion of urban communities according to the poverty line based on the province in the future. The data used is data from the National Statistics Agency through the website www.bps.go.id. The data is data on per capita income of urban communities on poverty line by province in 2013 semester 2 until 2016 semester 2. Algorithm used in this research is Artificial Neural Network with Backpropogation method. The input variables are data of year 2014 semester (X1), data of 2014 semester 1 (X2), data of 2014 semester 2 (X3), data of 2015 semester 1 (X4), data of 2015 semester 2 (X5) and data of 2016 semester 1 (X6) with architectural model of training and testing as much as 4 architecture that is 6-2-1, 6-6-1, 6-3-2-1 and 6-2-3-1. The output generated is the best pattern of the ANN architecture. The best architectural model is 6-3-2-1 with epoch 1190, MSE 0,0102524619 and 100\% accuracy rate. From this model, the prediction of per capita income of urban community on the poverty line is based on the provinces of each province in Indonesia.
\end{abstract}

Keywords: Income Per Capita, ANN, Backpropogation and Prediction

\begin{abstract}
Abstrak
Masalah kemiskinan merupakan salah satu persoalan mendasar yang menjadi pusat perhatian Pemerintah di negara manapun. Dalam Upaya mewujudkan ketentuan sebagaimana ditetapkan Pasal 28A Undang-Undang Dasar Negara Republik Indonesia Tahun 1945 yang menegaskan bahwa setiap orang berhak untuk hidup serta berhak mempertahankan hidup dan kehidupannya, maka Pemerintah Indonesia telah menetapkan program penanggulangan kemiskinan sebagai program prioritas. Sasaran primer kemiskinan mayoritas lebih banyak terdapat di perkotaan, sebab banyaknya para penduduk yang melakukan transmigrasi guna memperbaiki perekonomian namun malah gagal mendapatkan hasil. Penelitian ini memberikan kontribusi bagi pemerintah untuk dapat
\end{abstract}

JST Memprediksi Pendapatan Perkapita Masyarakat Perkotaan (Ahmad Revi)|122 
memprediksi pendapat perkapita masyarakat perkotaan menurut garis kemiskinan berdasarkan propinsi ke depan. Data yang digunakan adalah data dari Badan Statistik Nasional melalui website www.bps.go.id. Data tersebut adalah data pendapatan perkapita masyarakat perkotaan pada garis kemiskinan berdasarkan propinsi tahun 2013 semster 2 sampai dengan tahun 2016 semester 2. Algoritma yang digunakan pada penelitian ini adalah Jaringan Saraf Tiruan dengan metode Backpropogation. Variabel masukan (input) yang digunakan adalah data tahun 2013 semester 2(X1), data tahun 2014 semester 1(X2), data tahun 2014 semester 2(X3), data tahun 2015 semester 1(X4), data tahun 2015 semester 2(X5) dan data tahun 2016 semester 1(X6) dengan model arsitektur pelatihan dan pengujian sebanyak 4 arsitektur yakni 6-2-1, 6-6-1, 6-3-2-1 dan 6-2-3-1. Data target diambil dari data tahun 2016 semster 2. Keluaran yang dihasilkan adalah pola terbaik dari arsitektur JST. Model arsitektur terbaik adalah 6-3-2-1 dengan epoch 1190, MSE 0,0102524619 dan tingkat akurasi 100\%. Dari model ini maka dihasilkan prediksi pendapatan perkapita masyarakat perkotaan pada garis kemisikinan berdasarkan propinsi dari masing-masing propinsi di Indonesia.

Kata Kunci: Pendapata Perkapita, JST, Backpropogation dan Prediksi

\section{PENDAHULUAN}

Masalah kemiskinan merupakan salah satu persoalan mendasar yang menjadi pusat perhatian pemerintah di negara manapun. Dalam Upaya mewujudkan ketentuan sebagaimana ditetapkan Pasal 28A Undang-Undang Dasar Negara Republik Indonesia Tahun 1945 yang menegaskan bahwa setiap orang berhak untuk hidup serta berhak mempertahankan hidup dan kehidupannya, maka pemerintah Indonesia telah menetapkan program penanggulangan kemiskinan sebagai program prioritas.Sasaran primer kemiskinan mayoritas lebih banyak terdapat di perkotaan, sebab banyaknya para penduduk yang melakukan transmigrasi guna memperbaiki perekonomian namun malah gagal mendapatkan hasil.

Kemiskinan selalu berhubungan dengan pendapatan yang diperoleh oleh setiap masyarakat. Berdasarkan UUD Pasal 28D ayat (2), bahwa setiap warga negara berhak bekerja dan mendapat imbalan, maka masyarakat diberi kebebasan dalam memilih pekerjaan nya selama tidak menyimpang dari UU yang ada dan mempunyai "hak" nya masing-masing yaitu sebuah imbalan/pendapatan. Sumber pendapatan masyarakat antara lain pabrik industri, PNS, BUMN, investasi, buruh, pedagang dan lain-lain. Setiap pendapatan masyarakat yang diterima harus sesuai dengan upah minimum yang telah ditentukan oleh pemerintah. Menurut Pasal 90 2 ayat (1) UU No.13 Tahun 2003 tentang Ketenagakerjaan menyatakan bahwa "Pengushaha dilarang membayar upah lebih rendah dari upah minimum,......" . Berikut merupakan data pendapatan masyarakat perkotaan disusun berdasarkan kelompok umur pada tiap provinsi.

Perkembangan teknologi saat ini semakin pesat, menghantarkan semua aktifitas yang sulit untuk dilakukan oleh manusia dapat dikerjakan dengan mudah, efektif dan efisien. Adapun metode yang akan digunakan dalam penelitian ini adalah Jaringan Syaraf Tiruan (JST) . Dalam JST terdapat teknik peramalan yang 
dapat digunakan untuk melakukan prediksi yaitu backpropogation. Dengan menggunakan teknik ini dimaksudkan untuk membuat sebuah sistem yang dapat memprediksi pendapatan perkapita masyarakat dalam garis kemiskinan di setiap provinsi. Dengan adanya sistem ini diharapkan dapat membantu mengambil keputusan untuk melakukan kegiatan-kegiatan yang menyangkut tentang peningkatan pendapatan masyarakat sehingga kesejahteraan di perkotaan dapat merata.

\section{METODOLOGI PENELITIAN}

\subsection{Kecerdasan Buatan (Artificial Intelegent)}

Kecerdasan buatan atau disebut juga Artificial Intelegent (AI) merupakan salah satu bagian dari ilmu komputer yang mempelajari bagaimana membuat mesin (komputer) dapat melakukan pekerjaan seperti dan sebaik yang dilakukan oleh manusia bahkan bisa lebih baik daripada yang dilakukan manusia[1].

\subsection{Jaringan Saraf Tiruan}

Jaringan syaraf tiruan (JST) adalah paradigm pemrosesan suatu informasi yang terinspirasi oleh sistem sel syaraf biologi. Jaringan ini biasanya diimplementasikan dengan menggunakan komponen elektronik atau disimulasikan pada aplikasi computer[2].

\subsection{Arsitektur Backpropogation}

Backpropagation memiliki beberapa unit yang ada dalam satu atau lebih lapis tersembunyi. Pada gambar 2.7 di bawah adalah arsitektur Backpropagation dengan $n$ buah masukan $(x 1, x 2, x 3, \ldots \ldots . . x n)$ ditambah sebuah bias, sebuah lapis tersembunyi yang terdiri dari $j$ unit ditambah sebuah bias, serta $k$ buah unit keluaran[3]

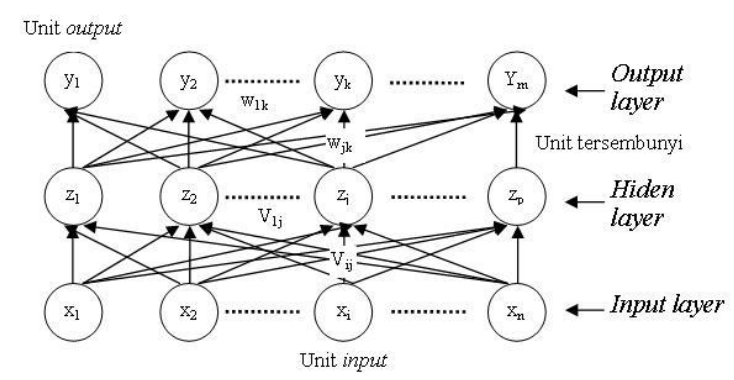

\section{Gambar 1 Arsitektur Backpropogation dengan 3 layer}

Simbol-simbol yang digunakan ini tidaklah mutlak, bisa saja berganti dengan simbol-simbol yang lainnya asalkan fungsi logika yang dimaksudkannya tetap sama. Secara sederhana dapat dikatakan bahwa jika output memberikan hasil yang salah, maka penimbang (bobot) dikoreksi supaya errornya (galat) dapat diperkecil dan respon jaringan selanjutnya diharapkan akan lebih mendekati harga yang benar. 


\subsection{Langkah-Langkah Jaringan Saraf Tiruan Backpropagation}

Langkah-langkah dalam Jaringan Saraf Tiruan Backpropagation meliputi tiga fase yaitu :

a. Fase I : Propagasi Maju

Selama propagasi maju, sinyal masukan $(=x i)$ dipropagasikan ke lapis tersembunyi menggunakan fungsi aktivasi yang ditentukan. Keluaran dari setiap unit lapis tersembunyi $(=z j)$ tersebut selanjutnya dipropagasikan maju lagi ke lapis tersembunyi di atasnya menggunakan fungsi aktivasi yang ditentukan. Demikian seterusnya hingga menghasilkan keluaran jaringan (= $y k)$. Berikutnya, keluaran jaringan $(=y k)$ dibandingkan dengan target yang harus dicapai $(=t k)$. Selisih $t k-y k$ adalah kesalahan yang terjadi. Jika kesalahan ini lebih kecil dari batas toleransi yang ditentukan, maka iterasi dihentikan. Akan tetapi apabila kesalahan masih lebih besar dari batas toleransinya, maka bobot setiap garis dalam jaringan akan dimodifikasikan untuk mengurangi kesalahan yang terjadi.

b. Fase II : Propagasi Mundur

Berdasarkan kesalahan $t k-y k$, dihitung faktor $\delta k(k=1,2, \ldots, m)$ yang dipakai untuk mendistribusikan kesalahan di unit $y k$ ke semua unit tersembunyi yang terhubung langsung dengan $y k . \delta k$ juga dipakai untuk mengubah bobot garis yang menghubungkan langsung dengan unit keluaran. Dengan cara yang sama, dihitung $\delta j$ di setiap unit di lapis tersembunyi sebagai dasar perubahan bobot semua garis yang berasal dari unit tersembunyi di lapis di bawahnya. Demikian seterusnya hingga faktor $\delta$ di unit tersembunyi yang berhubungan langsung dengan unit masukan dihitung.

c. Fase III : Perubahan Bobot

Setelah semua faktor $\delta$ dihitung, bobot semua garis dimodifikasi bersamaan. Perubahan bobot suatu garis didasarkan atas faktor $\delta$ neuron di lapis atasnya. Sebagai contoh, perubahan bobot garis yang menuju ke lapis keluaran didasarkan atas dasar $\delta k$ yang ada di unit keluaran. Ketiga fase tersebut diulang ulang terus hingga kondisi penghentian dipenuhi. Umumnya kondisi penghentian yang sering dipakai adalah jumlah iterasi atau kesalahan. Iterasi akan dihentikan jika jumlah iterasi yang dilakukan sudah melebihi jumlah maksimum iterasi yang ditetapkan, atau jika kesalahan yang terjadi sudah lebih kecil dari batas toleransi yang diijinkan [4].

Algoritma pelatihan untuk jaringan Backpropagation dengan satu layar tersembunyi (dengan fungsi aktivasi sigmoid biner) adalah [5]:

Langkah 0 : Inisialisasi semua bobot dengan bilangan acak kecil.

Langkah 1 : Jika kondisi penghentian belum dipenuhi, lakukan langkah 2-8.

Langkah 2 : Untuk setiap pasang data pelatihan, lakukan langkah 3-8.

Langkah 3 : Langkah 3 (langkah 3-5 merupakan fase 1).

Tiap unit masukan menerima sinyal dan meneruskannya ke unit tersembunyi diatasnya.

Langkah 4 : Hitung semua keluaran di unit tersembunyi zj $(j=1,2, \ldots, p)$.

$$
Z_{-} \text {net }_{j}=V_{j 0}+\sum_{\mathrm{i}=1}^{n} X_{\mathrm{i}} V_{j \mathrm{i}}
$$




$$
Z_{j}=f\left(Z_{-} \text {net }_{j}\right)=\frac{1}{1+\exp ^{\left(-z_{-} \text {net }_{j}\right)}}
$$

Langkah 5 : Hitung semua keluaran jaringan di unit keluaran $y k(k=1,2, \ldots, m)$ :

$$
y_{\text {net }}=W_{k o}+\sum_{j=1}^{p} Z_{j} W_{k j}
$$

Menghitung kembali sesuai dengan fungsi aktivasi:

$$
\begin{aligned}
y_{k} & =f\left(y_{1} n e t_{k)}\right. \\
Z_{j} & \left.=\frac{1}{1+\operatorname{Exp}^{\left(-y n_{n} x_{k}\right]}}\right)
\end{aligned}
$$

Langkah 6 : (langkah 6-7 merupakan fase 2)

Hitung faktor $\delta$ unit keluaran berdasarkan kesalahan di setiap unit keluaran $y k(k=1,2, \ldots, m)$.

$$
\begin{gathered}
\delta_{k}=\left(t_{k}-y_{k}\right) f^{\prime}\left(y_{-} n e t_{k}\right)=\left(t_{k}-y_{k}\right) y_{k}\left(1-y_{k}\right) \\
t_{k}=\text { target }
\end{gathered}
$$

keluaran $\delta k$ merupakan unit kesalahan yang akan dipakai dalam perubahan bobot layar dibawahnya. Hitung perubahan bobot $w k j$ dengan laju pemahaman $\alpha$.

$$
\Delta W_{k j}=\alpha \delta_{k} z_{j j}, k=1,2, \ldots, m, j=0,1, \ldots, p
$$

Langkah $7 \quad$ : Hitung faktor $\delta$ unit tersembunyi berdasarkan kesalahan di setiap unit tersembunyi zj $(j=1,2, \ldots, p)$

$$
\delta_{\text {net j }}=\sum_{k=1}^{m} \delta_{k} W_{k j}
$$

Faktor $\delta$ unit tersembunyi.

$$
\delta_{j}=\delta_{\text {net }_{j}} f^{\prime}\left(z_{-} \text {net }_{j}\right)=\delta_{\text {net }_{j}} z_{j}\left(1-z_{j}\right)
$$

Hitung suku perubahan bobot vji.

$$
\Delta V_{j i}=\alpha \delta_{j} x_{i}, j=1,2, \ldots, p, i=0,1, \ldots, n
$$

Langkah 8 : Hitung semua perubahan bobot. Perubahan bobot garis yang menuju ke unit keluaran, yaitu

$$
\begin{gathered}
W_{k j}(\text { baru })=W_{k j}(l a m a)+\Delta W_{k j}, \\
k=1,2, \ldots, m, j=0,1, \ldots, p n
\end{gathered}
$$

Perubahan bobot garis yang menuju ke unit tersembunyi, yaitu:

$$
\begin{gathered}
V_{j \mathrm{i}}(\text { baru })=V_{j i}(\text { lama })+\Delta V_{j \mathrm{i}}, \\
j=1,2, \ldots, p, i=0,1, \ldots, n
\end{gathered}
$$

\subsection{Karakteristik Jaringan Saraf Tiruan}

Jaringan Saraf Tiruan memiliki beberapa karakteristik yang unik, diantaranya adalah :

a. Kemampuan untuk belajar

b. Kemampuan untuk mengeneralisasi

c. 3. Kemampuan untuk menyolusikan permasalahan yang tidak bisa atau kurang baik bila dimodelkan sebagai sistem linier, yang menjadi persyaratan pada 
beberapa metode peramalan lainnya, seperti model data deret waktu (time series model][6].

\section{HASIL DAN PEMBAHASAN}

\subsection{Perancangan Sistem}

\subsubsection{Pendefinisian Input dan Target}

Data Perdapatan Perkapita Masyarakat Perkotaan Pada Garis KemiskinanBerdasarkan Propinsi akan diolah oleh Jaringan Saraf Tiruan dengan metode backpropogation. Agar data dapat dikenali oleh Jaringan Saraf Tiruan, maka data harus direpresentasikan ke dalam bentuk numerik antara 0 sampai dengan 1, baik variabel maupun isinya yang merupakan masukan data Data Perdapatan Perkapita Masyarakat Perkotaan sebagai pengenalan pola dan keluaran yang merupakan prediksi Data Perdapatan Perkapita Masyarakat Perkotaan Pada Garis Kemiskinan yang diperoleh dari model arsitektur terbaik pada saat penentuan pola terbaik. Hal ini dikarenakan jaringan menggunakan fungsi aktivasi sigmoid biner (logsig) yang rangenya dari 0 sampai 1 . Nilai-nilai yang digunakan diperoleh berdasarkan kategori dari masing-masing variabel selain juga untuk memudahkan mengingat dalam pendefinisiannya.

\subsubsection{Pendefinisian Input}

Variabel Data Perdapatan Perkapita Masyarakat Perkotaan Pada Garis Kemiskinan adalah kriteria yang menjadi acuan dalam pengambilan keputusan pada penilaian dengan menggunakan Jaringan Saraf Tiruan. Variabel ditentukan dengan cara melihat ketergantungan data terhadap penelitian yang dilakukan. Kriteria yang digunakan berdasarkan Data Badan Pusat Statistik Nasional dari website url: www.bps.go.id. Adapun daftar variabel dalam memprediksi Data Perdapatan Perkapita Masyarakat Perkotaan Pada Garis Kemiskinan tabel 1:

Tabel 1 : Daftar Kriteria Data Perdapatan Perkapita Masyarakat Perkotaan Pada Garis Kemiskinan

\begin{tabular}{rcc}
\hline No & Variabel & Nama Kriteria \\
\hline 1 & X1 & Data Tahun 2013 Semester 2 \\
2 & X2 & Data Tahun 2014 Semester 1 \\
3 & X3 & Data Tahun 2014 Semester 2 \\
4 & X4 & Data Tahun 2015 Semester 1 \\
5 & X5 & Data Tahun 2015 Semester 2 \\
6 & X6 & Data Tahun 2016 Semester 1 \\
\hline
\end{tabular}

Sumber : Badan Pusat Statistik Nasional

Data input diperoleh dari website Badan Pusat Statistik Nasional tentang Pendapatan Perkapita Masyarakat Perkotaan Pada Garis Kemiskinan Berdasarkan Propinsi. Data sampel yang digunakan adalah Pendapatan Perkapita Masyarakat Perkotaan Pada Garis Kemiskinan Berdasarkan Propinsi Tahun 2013 Semester 2 sampai Tahun 2016 Semester 2 yang terdiri dari 32 yang lengkap data dan masing masing data memiliki 6 variabel dan 1 target. Data ini nantinya akan 
ditransformasikan ke sebuah data antara 0 sampai 1 sebelum dilakukan pelatihan dan pengujian menggunakan Jaringan Saraf Tiruan metode backpropagation dengan rumus :

$$
x^{\prime}=\frac{0.8(x-a)}{b-a}+0.1
$$

\subsubsection{Pendefinisian Target}

Adapun data target adalah Data Pendapatan Perkapita Masyarakat Perkotaan Pada Garis Kemiskinan Berdasarkan Propinsi Tahun 2016 Semester 2.

\subsection{Pengolahan Data}

Pengolahan data dilakukan dengan bantuan Matlab 6.1 aplikasi perangkat lunak. Sampel Data adalah Pendapatan Perkapita Masyarakat Perkotaan Pada Garis Kemiskinan Berdasarkan Propinsi. Data ini akan digunakan pada data pelatihan dan data pengujian. Sampel data yang telah diproses dan ditranformasikan adalah sebagai berikut.

Tabel 2. Sampel Data Mentah Pendapatan Perkapita Masyarakat Perkotaan Pada Garis Kemiskinan Berdasarkan Propinsi

\begin{tabular}{|c|c|c|c|c|c|c|c|c|}
\hline \multirow{2}{*}{ No } & \multirow{2}{*}{ Nama } & \multicolumn{6}{|c|}{ Variabel } & \multirow{2}{*}{ Target } \\
\hline & & X1 & $x 2$ & X3 & $\mathrm{X} 4$ & $\mathrm{X} 5$ & $x 6$ & \\
\hline 1 & ACEH & 374261 & 383186 & 396939 & 410414 & 420324 & 427970 & 445488 \\
\hline 2 & SUMATERA UTARA & 330517 & 338234 & 349372 & 364320 & 379898 & 398408 & 413835 \\
\hline 3 & SUMATERA BARAT & 360768 & 374968 & 390862 & 406335 & 423339 & 441523 & 454674 \\
\hline 4 & RIAU & 366057 & 375286 & 386606 & 404802 & 417768 & 426346 & 439542 \\
\hline 5 & JAMBI & 369835 & 379183 & 390931 & 406074 & 423855 & 438600 & 448615 \\
\hline 6 & SUMATERA SELATAN & 328335 & 336929 & 346238 & 365336 & 378739 & 388060 & 400159 \\
\hline 7 & BENGKULU & 358294 & 362614 & 378881 & 397489 & 425642 & 430572 & 458435 \\
\hline 8 & LAMPUNG & 326468 & 336927 & 350024 & 370839 & 386728 & 392488 & 398378 \\
\hline 9 & KEP. BANGKA BELITUNG & 416935 & 439377 & 458055 & 475478 & 516835 & 521773 & 553681 \\
\hline 10 & KEP. RIAU & 405578 & 421733 & 431127 & 454147 & 485496 & 494418 & 505980 \\
\hline 11 & DKI JAKARTA & 434322 & 447797 & 459560 & 487388 & 503038 & 510359 & 520690 \\
\hline 12 & JAWA BARAT & 281189 & 288742 & 294700 & 307487 & 318297 & 325017 & 332145 \\
\hline 13 & JAWA TENGAH & 268397 & 279036 & 286014 & 299011 & 308163 & 315269 & 322799 \\
\hline 14 & DI YOGYAKARTA & 317925 & 327273 & 333561 & 347787 & 359470 & 364786 & 370510 \\
\hline 15 & JAWA TIMUR & 278653 & 287582 & 293391 & 304918 & 314320 & 319662 & 329241 \\
\hline 16 & BANTEN & 300109 & 315239 & 324902 & 344855 & 365672 & 377052 & 382903 \\
\hline 17 & BALI & 298449 & 310321 & 316235 & 332999 & 341554 & 348571 & 357427 \\
\hline 18 & NUSA TENGGARA BARAT & 299886 & 307147 & 315470 & 328125 & 335284 & 343580 & 346581 \\
\hline 19 & NUSA TENGGARA TIMUR & 321163 & 337367 & 340459 & 364920 & 374355 & 386139 & 389661 \\
\hline 20 & KALIMANTAN BARAT & 280423 & 291533 & 307789 & 334575 & 347516 & 353143 & 366477 \\
\hline 21 & KALIMANTAN TENGAH & 299970 & 307382 & 316683 & 328674 & 339239 & 348254 & 357224 \\
\hline 22 & KALIMANTAN SELATAN & 313691 & 322006 & 336782 & 354103 & 371793 & 386462 & 399162 \\
\hline 23 & KALIMANTAN TIMUR & 435313 & 448220 & 459004 & 485887 & 504551 & 519653 & 535137 \\
\hline
\end{tabular}


Kumpulan jurnaL Ilmu Komputer (KLIK) Volume 05, No.02 September 2018

ISSN: 2406-7857

\begin{tabular}{|c|c|c|c|c|c|c|c|c|}
\hline \multirow{2}{*}{ No } & \multirow{2}{*}{ Nama } & \multicolumn{6}{|c|}{ Variabel } & \multirow{2}{*}{ Target } \\
\hline & & $\mathrm{X} 1$ & $\mathrm{X} 2$ & X3 & $\mathrm{X} 4$ & $\times 5$ & $x 6$ & \\
\hline 24 & SULAWESI UTARA & 255566 & 265093 & 269212 & 290820 & 302378 & 312328 & 314004 \\
\hline 25 & SULAWESI TENGAH & 324072 & 336900 & 349978 & 358399 & 376496 & 391070 & 399413 \\
\hline 26 & SULAWESI SELATAN & 235488 & 240276 & 246416 & 262163 & 274140 & 281676 & 286669 \\
\hline 27 & SULAWESI TENGGARA & 240089 & 241921 & 254015 & 269703 & 282230 & 289827 & 294286 \\
\hline 28 & GORONTALO & 237600 & 246633 & 250157 & 263288 & 274581 & 284308 & 287156 \\
\hline 29 & SULAWESI BARAT & 230973 & 235934 & 245959 & 257004 & 269080 & 273224 & 280117 \\
\hline 30 & MALUKU & 358068 & 362783 & 369738 & 400347 & 404929 & 412980 & 424788 \\
\hline 31 & MALUKU UTARA & 317176 & 321231 & 339561 & 360933 & 378538 & 390788 & 405368 \\
\hline 32 & PAPUA BARAT & 414900 & 416158 & 440241 & 452022 & 478699 & 487727 & 508262 \\
\hline
\end{tabular}

Sumber : Badan Pusat Statistik Nasional

Tabel 3. Sampel dari data yang telah ditransformasikan

\begin{tabular}{rlllccccc}
\hline \multirow{2}{*}{ No } & Nama & \multicolumn{7}{c}{ Variabel } \\
\cline { 2 - 7 } & & $\mathrm{X} 1$ & $\mathrm{X} 2$ & $\mathrm{X3}$ & $\mathrm{X} 4$ & $\mathrm{X} 5$ & $\mathrm{X6}$ & Target \\
\hline 1 & Data 1 & 0,4552 & 0,4773 & 0,5114 & 0,5448 & 0,5694 & 0,5884 & 0,6318 \\
2 & Data 2 & 0,3468 & 0,3659 & 0,3935 & 0,4306 & 0,4692 & 0,5151 & 0,5533 \\
3 & Data 3 & 0,4218 & 0,4570 & 0,4964 & 0,5347 & 0,5769 & 0,6220 & 0,6546 \\
4 & Data 4 & 0,4349 & 0,4578 & 0,4858 & 0,5309 & 0,5631 & 0,5843 & 0,6170 \\
5 & Data 5 & 0,4442 & 0,4674 & 0,4965 & 0,5341 & 0,5782 & 0,6147 & 0,6395 \\
6 & Data 6 & 0,3414 & 0,3627 & 0,3857 & 0,4331 & 0,4663 & 0,4894 & 0,5194 \\
7 & Data 7 & 0,4156 & 0,4263 & 0,4667 & 0,5128 & 0,5826 & 0,5948 & 0,6639 \\
8 & Data 8 & 0,3367 & 0,3627 & 0,3951 & 0,4467 & 0,4861 & 0,5004 & 0,5150 \\
9 & Data 9 & 0,5610 & 0,6166 & 0,6629 & 0,7061 & 0,8087 & 0,8209 & 0,9000 \\
10 & Data 10 & 0,5328 & 0,5729 & 0,5962 & 0,6533 & 0,7310 & 0,7531 & 0,7817 \\
11 & Data 11 & 0,6041 & 0,6375 & 0,6667 & 0,7357 & 0,7745 & 0,7926 & 0,8182 \\
12 & Data 12 & 0,2245 & 0,2432 & 0,2580 & 0,2897 & 0,3165 & 0,3331 & 0,3508 \\
13 & Data 13 & 0,1928 & 0,2191 & 0,2364 & 0,2687 & 0,2914 & 0,3090 & 0,3276 \\
14 & Data 14 & 0,3156 & 0,3387 & 0,3543 & 0,3896 & 0,4185 & 0,4317 & 0,4459 \\
15 & Data 15 & 0,2182 & 0,2403 & 0,2547 & 0,2833 & 0,3066 & 0,3199 & 0,3436 \\
16 & Data 16 & 0,2714 & 0,3089 & 0,3329 & 0,3823 & 0,4339 & 0,4621 & 0,4766 \\
17 & Data 17 & 0,2673 & 0,2967 & 0,3114 & 0,3529 & 0,3741 & 0,3915 & 0,4135 \\
18 & Data 18 & 0,2708 & 0,2888 & 0,3095 & 0,3408 & 0,3586 & 0,3792 & 0,3866 \\
19 & Data 19 & 0,3236 & 0,3638 & 0,3714 & 0,4321 & 0,4554 & 0,4847 & 0,4934 \\
20 & Data 20 & 0,2226 & 0,2501 & 0,2904 & 0,3568 & 0,3889 & 0,4029 & 0,4359 \\
21 & Data 21 & 0,2710 & 0,2894 & 0,3125 & 0,3422 & 0,3684 & 0,3907 & 0,4130 \\
22 & Data 22 & 0,3051 & 0,3257 & 0,3623 & 0,4052 & 0,4491 & 0,4855 & 0,5169 \\
23 & Data 23 & 0,6066 & 0,6386 & 0,6653 & 0,7319 & 0,7782 & 0,8156 & 0,8540 \\
24 & Data 24 & 0,1610 & 0,1846 & 0,1948 & 0,2484 & 0,2770 & 0,3017 & 0,3058 \\
25 & Data 25 & 0,3308 & 0,3626 & 0,3950 & 0,4159 & 0,4608 & 0,4969 & 0,5176 \\
26 & Data 26 & 0,1112 & 0,1231 & 0,1383 & 0,1773 & 0,2070 & 0,2257 & 0,2381 \\
27 & Data 27 & 0,1226 & 0,1271 & 0,1571 & 0,1960 & 0,2271 & 0,2459 & 0,2570 \\
& & & & & & & &
\end{tabular}




\begin{tabular}{|c|c|c|c|c|c|c|c|c|}
\hline \multirow{2}{*}{ No } & \multirow{2}{*}{ Nama } & \multicolumn{6}{|c|}{ Variabel } & \multirow{2}{*}{ Target } \\
\hline & & $\mathrm{X} 1$ & $\mathrm{X} 2$ & X3 & $\mathrm{X} 4$ & $\mathrm{X} 5$ & $\mathrm{X} 6$ & \\
\hline 28 & Data 28 & 0,1164 & 0,1388 & 0,1476 & 0,1801 & 0,2081 & 0,2322 & 0,2393 \\
\hline 29 & Data 29 & 0,1000 & 0,1123 & 0,1372 & 0,1645 & 0,1945 & 0,2047 & 0,2218 \\
\hline 30 & Data 30 & 0,4151 & 0,4268 & 0,4440 & 0,5199 & 0,5312 & 0,5512 & 0,5805 \\
\hline 31 & Data 31 & 0,3137 & 0,3238 & 0,3692 & 0,4222 & 0,4658 & 0,4962 & 0,5323 \\
\hline 32 & Data 32 & 0,5560 & 0,5591 & 0,6188 & 0,6480 & 0,7141 & 0,7365 & 0,7874 \\
\hline
\end{tabular}

Sumber : Badan Pusat Statistik Nasional

\subsection{Perancangan Arsitektur Jaringan Saraf Tiruan}

Jaringan yang digunakan untuk dalam memprediksi Pendapatan Perkapita Masyarakat Perkotaan Pada Garis Kemiskinan Berdasarkan Propinsi dengan backpropogation dengan langkah pembelajaran feedforward. Jaringan ini memiliki beberapa lapisan, yaitu lapisan masukan (input), lapisan keluaran (output) dan beberapa lapisan tersembunyi (hidden). Lapisan tersembunyi tersebut membantu jaringan untuk dapat mengenali lebih banyak pola masukan dibandingkan dengan jaringan yang tidak memiliki lapisan tersembunyi. Parameter-parameter dalam pembentukan jaringan backpropagation menggunakan 6 variabel masukan, 1 atau lebih lapisan tersembunyi dan 1 lapisan keluaran. Adapun model arsitektur yang digunakan untuk mendapatkan arsitektur terbaik adalah 6-2-1, 6-6-1, 6-3-2-1 dan 6-2-3-1. Model sampel arsitektur 6-2-1 dapat dilihat pada gambar dibawah ini:

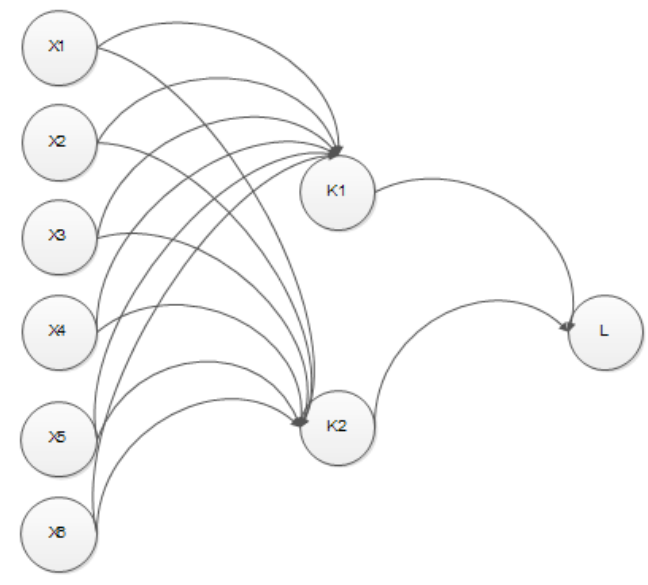

Gambar 1. Arsitektur Jaringan Saraf Tiruan dalam memprediksi Pendapatan Perkapita Masyarakat Perkotaan Pada Garis Kemiskinan Berdasarkan Propinsi

Jaringan Saraf yang akan dibangun adalah algoritma propagasi balik (backpropagation) dengan fungsi aktivasi Sigmoid. Fungsi aktivasi dalam Jaringan Saraf Tiruan dipakai untuk proses perhitungan terhadap nilai aktual output pada hidden layer dan menghitung nilai aktual output pada output layer.

\subsection{Pendefinisian Output}

Hasil yang diharapkan pada tahap ini adalah deteksi pola menentukan nilai terbaik untuk memprediksi Pendapatan Perkapita Masyarakat Perkotaan Pada Garis Kemiskinan Berdasarkan Propinsi. Hasil pengujian adalah sebagai berikut: 
a. Untuk mengetahui prediksi Pendapatan Perkapita Masyarakat Perkotaan Pada Garis Kemiskinan Berdasarkan Propinsi tentu saja didasarkan pada Data Pendapatan Perkapita Masyarakat Perkotaan Pada Garis Kemiskinan Berdasarkan Propinsi. Output dari prediksi ini adalah pola arsitektur terbaik dalam memprediksi Pendapatan Perkapita Masyarakat Perkotaan Pada Garis Kemiskinan Berdasarkan Propinsi dengan melihat error minimum.

b. Kategorisasi Output pelatihan (train) dan pengujian (test) Kategori untuk output ditentukan oleh tingkat error minimum dari target. Batasan kategori tersebut terdapat pada tabel berikut:

Tabel 4. Data Kategorisasi

\begin{tabular}{clcc}
\hline No & & Keterangan & Error Minimum \\
\hline 1 & Benar & & $0.05-0.001$ \\
2 & Salah & $>0.05$ \\
\hline
\end{tabular}

\subsection{Perancangan arsitektur Jaringan Saraf Tiruan}

Perancangan arsitektur Jaringan Saraf Tiruan untuk data pelatihan dan pengujian, maka digunakan 6 variabel input yaitu:

$\begin{array}{lll}X_{1} & = & \text { Data Tahun 2013 Semester 2 } \\ X_{2} & = & \text { Data Tahun 2014 Semester 1 } \\ X_{3} & = & \text { Data Tahun 2014 Semester 2 } \\ X_{4} & = & \text { Data Tahun 2015 Semester 1 } \\ X_{5} & = & \text { Data Tahun 2015 Semester 2 } \\ X_{6} & = & \text { Data Tahun 2016 Semester 1 }\end{array}$

Berikut tahapan-tahapan yang akan dilakukan dalam pengguna algoritma propagasi balik dengan fungsi aktivasi sigmoid. Tahapan yang harus dilakukan adalah sebagi berikut:

a. Inisialisasi (initialization), merupakan tahap di mana variabel-variabel nilai akan diset atau didefinisikan terlebih dahulu, misalnya seperti: nilai data input, weight, nilai output yang diharapkan, learning rate dan nilai-nilai data lainnya.

b. Aktivasi (activation),merupakan proses perhitungan terhadap nilai aktual output pada hidden layer dan menghitung nilai actual output pada output layer.

c. Weight Training, merupakan proses perhitungan nilai error gradient pada output layer dan menghitung nilai error gradient pada hidden layer

d. Iteration, merupakan tahap akhir dalam penggujian, dimana jika masih terjadi error minimum yang diharapkan belum ditemukan maka kembali pada tahap aktivasi (activation). 


\subsubsection{Pelatihan dan Pengujian Arsitektur 6-2-1}

Data Pendapatan Perkapita Masyarakat Perkotaan Pada Garis Kemiskinan Berdasarkan Propinsi terdiri dari 32 Data. Data dibagi menjadi 2 bagian yaitu 16 data pelatihan dan 16 data pengujian. Berikut adalah hasil pengujian dengan 16 data pengujian dengan pola pengujian 6-2-1. Data hasil pengujian dan Pelatihan dapat dilihat pada tabel sebagai berikut:

Tabel 5. Hasil Pelatihan dan Pengujian dengan Model 6-2-1

\begin{tabular}{rccccccccc}
\hline \multicolumn{1}{c}{ Pelatihan (Train) } & \multicolumn{7}{c}{ Pengujian (Test) } \\
\hline No & Target & $\begin{array}{c}\text { Output } \\
\text { JST }\end{array}$ & Error & SSE & No & Target & $\begin{array}{c}\text { Output } \\
\text { JST }\end{array}$ & Error & SSE \\
\hline 1 & 0,6318 & 0,6613 & $-0,0295$ & 0,0008702500 & 1 & 0,4135 & 0,4399 & $-0,0264$ & 0,0006969600 \\
2 & 0,5533 & 0,4659 & 0,0874 & 0,0076387600 & 2 & 0,3866 & 0,4412 & $-0,0546$ & 0,0029811600 \\
3 & 0,6546 & 0,6529 & 0,0017 & 0,0000028900 & 3 & 0,4934 & 0,4420 & 0,0514 & 0,0026419600 \\
4 & 0,6170 & 0,6270 & $-0,0100$ & 0,0001000000 & 4 & 0,4359 & 0,4503 & $-0,0144$ & 0,0002073600 \\
5 & 0,6395 & 0,6618 & $-0,0223$ & 0,0004972900 & 5 & 0,4130 & 0,4460 & $-0,0330$ & 0,0010890000 \\
6 & 0,6318 & 0,4507 & 0,1811 & 0,0327972100 & 6 & 0,5169 & 0,4566 & 0,0603 & 0,0036360900 \\
7 & 0,5533 & 0,6129 & $-0,0596$ & 0,0035521600 & 7 & 0,8540 & 0,7205 & 0,1335 & 0,0178222500 \\
8 & 0,6546 & 0,4566 & 0,1980 & 0,0392040000 & 8 & 0,3058 & 0,4748 & $-0,1690$ & 0,0285610000 \\
9 & 0,6170 & 0,7344 & $-0,1174$ & 0,0137827600 & 9 & 0,5176 & 0,4717 & 0,0459 & 0,0021068100 \\
10 & 0,6395 & 0,7293 & $-0,0898$ & 0,0080640400 & 10 & 0,2381 & 0,4967 & $-0,2586$ & 0,0668739600 \\
11 & 0,8182 & 0,7174 & 0,1008 & 0,0101606400 & 11 & 0,2570 & 0,4939 & $-0,2369$ & 0,0561216100 \\
12 & 0,3508 & 0,4555 & $-0,1047$ & 0,0109620900 & 12 & 0,2393 & 0,4997 & $-0,2604$ & 0,0678081600 \\
13 & 0,3276 & 0,4663 & $-0,1387$ & 0,0192376900 & 13 & 0,2218 & 0,5031 & $-0,2813$ & 0,0791296900 \\
14 & 0,4459 & 0,4363 & 0,0096 & 0,0000921600 & 14 & 0,5805 & 0,5370 & 0,0435 & 0,0018922500 \\
15 & 0,3436 & 0,4561 & $-0,1125$ & 0,0126562500 & 15 & 0,5323 & 0,4525 & 0,0798 & 0,0063680400 \\
16 & 0,4766 & 0,4568 & 0,0198 & 0,0003920400 & 16 & 0,7874 & 0,7290 & 0,0584 & 0,0034105600 \\
& & Total & & 0,1600102300 & & & Total & & 0,3413468600 \\
& & MSE & & 0,0100006394 & & & MSE & & 0,0213341788 \\
& & & $75 \%$ & & & Akurasi Kebenaran (\%) & $\mathbf{7 5 \%}$ \\
\hline
\end{tabular}

\subsubsection{Pelatihan dan Pengujian Arsitektur 6-6-1}

Berikut adalah hasil pengujian dengan 16 data pengujian dengan pola pengujian 6-6-1. Data hasil pengujian dan Pelatihan dapat dilihat pada tabel sebagai berikut:

Tabel 6. Hasil Pelatihan dan Pengujian dengan Model 6-6-1

\begin{tabular}{rccccccccc}
\hline \multicolumn{1}{c}{ Pelatihan (Train) } & \multicolumn{1}{c}{ Pengujian (Test) } \\
\hline No & Target & $\begin{array}{c}\text { Output } \\
\text { JST }\end{array}$ & Error & SSE & No & Target & $\begin{array}{c}\text { Output } \\
\text { JST }\end{array}$ & Error & SSE \\
\hline 1 & 0,6318 & 0,6472 & $-0,0154$ & 0,0002371600 & 1 & 0,4135 & 0,4005 & 0,0130 & 0,0001690000 \\
2 & 0,5533 & 0,6138 & $-0,0605$ & 0,0036602500 & 2 & 0,3866 & 0,3766 & 0,0100 & 0,0001000000 \\
3 & 0,6546 & 0,6613 & $-0,0067$ & 0,0000448900 & 3 & 0,4934 & 0,5904 & $-0,0970$ & 0,0094090000 \\
4 & 0,6170 & 0,6482 & $-0,0312$ & 0,0009734400 & 4 & 0,4359 & 0,3780 & 0,0579 & 0,0033524100 \\
5 & 0,6395 & 0,6529 & $-0,0134$ & 0,0001795600 & 5 & 0,4130 & 0,3889 & 0,0241 & 0,0005808100 \\
6 & 0,6318 & 0,6023 & 0,0295 & 0,0008702500 & 6 & 0,5169 & 0,5803 & $-0,0634$ & 0,0040195600
\end{tabular}


Kumpulan jurnaL Ilmu Komputer (KLIK)

Volume 05, No.02 September 2018

ISSN: $2406-7857$

\begin{tabular}{rccccccccc}
\hline \multicolumn{1}{c}{ Pelatihan (Train) } & \multicolumn{5}{c}{ Pengujian (Test) } \\
\hline No & Target & $\begin{array}{c}\text { Output } \\
\text { JST }\end{array}$ & Error & SSE & No & Target & $\begin{array}{c}\text { Output } \\
\text { JST }\end{array}$ & Error & SSE \\
\hline 7 & 0,5533 & 0,6598 & $-0,1065$ & 0,0113422500 & 7 & 0,8540 & 0,6570 & 0,1970 & 0,0001690000 \\
8 & 0,6546 & 0,6220 & 0,0326 & 0,0010627600 & 8 & 0,3058 & 0,0862 & 0,2196 & 0,0388090000 \\
9 & 0,6170 & 0,6647 & $-0,0477$ & 0,0022752900 & 9 & 0,5176 & 0,5951 & $-0,0775$ & 0,0482241600 \\
10 & 0,6395 & 0,6611 & $-0,0216$ & 0,0004665600 & 10 & 0,2381 & 0,0563 & 0,1818 & 0,0060062500 \\
11 & 0,8182 & 0,6551 & 0,1631 & 0,0266016100 & 11 & 0,2570 & 0,0626 & 0,1944 & 0,0330512400 \\
12 & 0,3508 & 0,1796 & 0,1712 & 0,0293094400 & 12 & 0,2393 & 0,0555 & 0,1838 & 0,0377913600 \\
13 & 0,3276 & 0,1216 & 0,2060 & 0,0424360000 & 13 & 0,2218 & 0,543 & 0,1675 & 0,0337824400 \\
14 & 0,4459 & 0,5246 & $-0,0787$ & 0,0061936900 & 14 & 0,5805 & 0,6464 & $-0,0659$ & 0,0280562500 \\
15 & 0,3436 & 0,1626 & 0,1810 & 0,0327610000 & 15 & 0,5323 & 0,6095 & $-0,0772$ & 0,0043428100 \\
16 & 0,4766 & 0,5159 & $-0,0393$ & 0,0015444900 & 16 & 0,7874 & 0,6621 & 0,1253 & 0,0059598400 \\
& & & & 0,1599586400 & & & Total & & 0,2693542200 \\
& & MSE & & 0,0099974150 & & & MSE & & 0,0168346390 \\
& & & & & Akurasi Kebenaran (\%) & $\mathbf{1 0 0} \%$ \\
\hline
\end{tabular}

\subsubsection{Pelatihan dan Pengujian Arsitektur 6-3-2-1}

Berikut adalah hasil pengujian dengan 16 data pengujian dengan pola pengujian 6-3-2-1. Data hasil pengujian dan Pelatihan dapat dilihat pada tabel sebagai berikut:

Tabel 7. Hasil Pelatihan dan Pengujian dengan Model 6-3-2-1

\begin{tabular}{rccccccccc}
\hline \multicolumn{1}{c}{ Pelatihan (Train) } & \multicolumn{7}{c}{ Pengujian (Test) } \\
\hline No & Target & $\begin{array}{c}\text { Output } \\
\text { JST }\end{array}$ & Error & SSE & No & Target & $\begin{array}{c}\text { Output } \\
\text { JST }\end{array}$ & Error & SSE \\
\hline 1 & 0,6318 & 0,6964 & $-0,0646$ & 0,0041731600 & 1 & 0,4135 & 0,4168 & $-0,0033$ & 0,0000108900 \\
2 & 0,5533 & 0,6679 & $-0,1146$ & 0,0131331600 & 2 & 0,3866 & 0,3828 & 0,0038 & 0,0000144400 \\
3 & 0,6546 & 0,7123 & $-0,0577$ & 0,0033292900 & 3 & 0,4934 & 0,6546 & $-0,1612$ & 0,0259854400 \\
4 & 0,6170 & 0,7011 & $-0,0841$ & 0,0070728100 & 4 & 0,4359 & 0,3389 & 0,0970 & 0,0094090000 \\
5 & 0,6395 & 0,7073 & $-0,0678$ & 0,0045968400 & 5 & 0,4130 & 0,3988 & 0,0142 & 0,0002016400 \\
6 & 0,6318 & 0,6522 & $-0,0204$ & 0,0004161600 & 6 & 0,5169 & 0,6182 & $-0,1013$ & 0,0102616900 \\
7 & 0,5533 & 0,7035 & $-0,1502$ & 0,0225600400 & 7 & 0,8540 & 0,6471 & 0,2069 & 0,0428076100 \\
8 & 0,6546 & 0,6615 & $-0,0069$ & 0,0000476100 & 8 & 0,3058 & 0,2001 & 0,1057 & 0,0111724900 \\
9 & 0,6170 & 0,6760 & $-0,0590$ & 0,0034810000 & 9 & 0,5176 & 0,6525 & $-0,1349$ & 0,0181980100 \\
10 & 0,6395 & 0,7060 & $-0,0665$ & 0,0044222500 & 10 & 0,2381 & 0,1888 & 0,0493 & 0,0024304900 \\
11 & 0,8182 & 0,6424 & 0,1758 & 0,0309056400 & 11 & 0,2570 & 0,1893 & 0,0677 & 0,0045832900 \\
12 & 0,3508 & 0,2312 & 0,1196 & 0,0143041600 & 12 & 0,2393 & 0,1894 & 0,0499 & 0,0024900100 \\
13 & 0,3276 & 0,2067 & 0,1209 & 0,0146168100 & 13 & 0,2218 & 0,1865 & 0,0353 & 0,0012460900 \\
14 & 0,4459 & 0,5705 & $-0,1246$ & 0,0155251600 & 14 & 0,5805 & 0,6960 & $-0,1155$ & 0,0133402500 \\
15 & 0,3436 & 0,2216 & 0,1220 & 0,0148840000 & 15 & 0,5323 & 0,6309 & $-0,0986$ & 0,0097219600 \\
16 & 0,4766 & 0,5568 & $-0,0802$ & 0,0064320400 & 16 & 0,7874 & 0,6771 & 0,1103 & 0,0121660900 \\
& & Total & & 0,1599001300 & & & Total & & 0,1640393900 \\
& & MSE & & 0,0099937581 & & & MSE & & 0,0102524619 \\
& & & & & & Akurasi Kebenaran (\%) & $\mathbf{1 0 0 \%}$ \\
\hline
\end{tabular}




\subsubsection{Pelatihan dan Pengujian Arsitektur 6-2-3-1}

Berikut adalah hasil pengujian dengan 16 data pengujian dengan pola pengujian 6-2-6-1. Data hasil pengujian dan Pelatihan dapat dilihat pada tabel sebagai berikut:

Tabel 8. Hasil Pelatihan dan Pengujian dengan Model 6-2-3-1

\begin{tabular}{|c|c|c|c|c|c|c|c|c|c|}
\hline \multicolumn{5}{|c|}{ Pelatihan (Train) } & \multicolumn{5}{|c|}{ Pengujian (Test) } \\
\hline No & Target & $\begin{array}{c}\text { Output } \\
\text { JST }\end{array}$ & Error & SSE & No & Target & $\begin{array}{c}\text { Output } \\
\text { JST }\end{array}$ & Error & SSE \\
\hline 1 & 0,6318 & 0,5545 & 0,0773 & 0,0059752900 & 1 & 0,4135 & 0,5074 & $-0,0939$ & 0,0088172100 \\
\hline 2 & 0,5533 & 0,5192 & 0,0341 & 0,0011628100 & 2 & 0,3866 & 0,5059 & $-0,1193$ & 0,0142324900 \\
\hline 3 & 0,6546 & 0,5502 & 0,1044 & 0,0108993600 & 3 & 0,4934 & 0,5204 & $-0,0270$ & 0,0007290000 \\
\hline 4 & 0,6170 & 0,5476 & 0,0694 & 0,0048163600 & 4 & 0,4359 & 0,4982 & $-0,0623$ & 0,0038812900 \\
\hline 5 & 0,6395 & 0,5535 & 0,0860 & 0,0073960000 & 5 & 0,4130 & 0,5030 & $-0,0900$ & 0,0081000000 \\
\hline 6 & 0,6315 & 0,5217 & 0,1101 & 0,0121220100 & 6 & 0,5169 & 0,5083 & 0,0086 & 0,0000739600 \\
\hline 7 & 0,5533 & 0,5439 & 0,0094 & 0,0000883600 & 7 & 0,8540 & 0,7232 & 0,1308 & 0,0171086400 \\
\hline 8 & 0,6546 & 0,5223 & 0,1323 & 0,0175032900 & 8 & 0,3085 & 0,4627 & $-0,1569$ & 0,0246176100 \\
\hline 9 & 0,6170 & 0,7534 & $-0,1364$ & 0,0186049600 & 9 & 0,5176 & 0,5114 & 0,0062 & 0,0000384400 \\
\hline 10 & 0,6395 & 0,6913 & $-0,0518$ & 0,0026832400 & 10 & 0,2381 & 0,4146 & $-0,1765$ & 0,0311522500 \\
\hline 11 & 0,8182 & 0,7147 & 0,1035 & 0,0107122500 & 11 & 0,2570 & 0,4231 & $-0,1661$ & 0,0275892100 \\
\hline 12 & 0,3508 & 0,4899 & $-0,1391$ & 0,0193488100 & 12 & 0,2393 & 0,4088 & $-0,1695$ & 0,0287302500 \\
\hline 13 & 0,3276 & 0,4761 & $-0,1485$ & 0,0220522500 & 13 & 0,2218 & 0,3974 & $-0,1756$ & 0,0308353600 \\
\hline 14 & 0,4459 & 0,5166 & $-0,0707$ & 0,0049984900 & 14 & 0,5805 & 0,5391 & 0,0414 & 0,0017139600 \\
\hline 15 & 0,3436 & 0,4887 & $-0,1451$ & 0,0210540100 & 15 & 0,5323 & 0,5140 & 0,0183 & 0,0003348900 \\
\hline 16 & 0,4766 & 0,5004 & $-0,0238$ & 0,0005664400 & 16 & 0,7874 & 0,7038 & 0,0836 & 0,0069889600 \\
\hline & & Total & & 0,1599839300 & & & Total & & 0,2049435200 \\
\hline & & MSE & & 0,0099989956 & & & MSE & & 0,0128089700 \\
\hline & & & & & & Akuras & Kebenaraı & & $100 \%$ \\
\hline
\end{tabular}

\subsubsection{Pemilihan Arsitektur Terbaik Jaringan Saraf Tiruan}

Hasil software aplikasi Matlab 6.1 yang digunakan untuk model arsitektur 6-2-1, arsitektur 6-6-1, arsitektur 6-3-2-1 dan arsitektur 6-2-3-1 adalah memperoleh pola arsitektur terbaik. Dari pola ini nanti akan digunakan untuk mempredikasi Pendapatn Perkapita Masyarakat Perkotaan Pada Garis Kemiskinan. Penilaian model arsitektur terbaik dilihat dari beberapa aspek seperti epoch, error minimum dan akurasi kebenaran . Untuk lebih jelas dapat dilihat pada berikut :

Tabel 9. Rekapitulasi Model Arsitektur

\begin{tabular}{|l|cccc|} 
Model & $6-2-1$ & $6-6-1$ & $6-3-2-1$ & $6-2-3-1$ \\
Epochs & 6545 & 5035 & 1190 & 37535 \\
MSE & 0,0213341788 & 0,0168346390 & 0,0102524619 & 0,0128089700 \\
Akurasi & $75 \%$ & $100 \%$ & $100 \%$ & $100 \%$
\end{tabular}


Dari tabel 9 dapat dilihat bahwa model arsitektur terbaik yang akan digunakan untuk melakukan prediksi dari serangkaian uji coba model adalah 6-3-2-1 dengan epoch 1190, MSE 0,0102524619 dan tingkat akurasi 100\%.

\section{KESIMPULAN}

Berdasarkan hasil dan pembahasan diatas, maka penulis dapat mengambil kesimpulan sebagai berikut :

a. Setelah dilakukan percobaan dalam proses pelatihan dan pengujian sistem yang dilakukan dengan menggunakan software aplikasi Matlab 6.1. Model Jaringan Syaraf Tiruan yang digunakan adalah 6-2-1, model 6-6-1, model 6-32-1 dan model 6-2-3-1, dapat diperoleh hasil yang baik dengan melihat MSE Pengujian yang terkecil adalah 6-3-2-1.

b. Dengan model arsitektur 6-3-2-1, dapat melakukan prediksi Pendapatan Perkapita Masyarakat Perkotaan Pada Garis Kemiskinan Berdasarkan Propinsi dengan menunjukkan performa $100 \%$.

\section{UCAPAN TERIMA KASIH}

Ucapan terima kasih kami sampaikan kepada Direktorat Jendral Pembelajaran Dan Kemahasiswaan Kementerian Riset, Teknologi dan Pendidikan Tinggi atas pendanaan Program Kreativitas Mahasiswa Penelitian (PKM-PE) tahun pelaksanaan 2018.

\section{DAFTAR PUSTAKA}

[1] M. Solikhun, Agus Perdana Windarto, Handrizal and Fauzan, "Jaringan Saraf Tiruan Dalam Memprediksi Sukuk Negara Ritel Berdasarkan Kelompok Profesi Dengan Backpropagation Dalam Mendorong Laju Pertumbuhan Ekonomi," pp. 14-31, 2017.

[2] A. T. Solikhun, M. Safii, "Jaringan Saraf Tiruan Untuk Memprediksi Tingkat Pemahaman Siswa Terhadap Matapelajaran Dengan Menggunakan Algoritma Backpropagation," no. 1, pp. 24-36, 2017.

[3] Z. A. Matondang, "Jaringan Syaraf Tiruan Dengan Algoritma Backpropagation Untuk Penentuan Kelulusan Sidang Skripsi," Pelita Inform. Budi Darma, vol. IV, no. 1, pp. 84-93, 2013.

[4] A. Jumarwanto, "Aplikasi Jaringan Saraf Tiruan Backpropagation Untuk Memprediksi Penyakit THT Di Rumah Sakik Mardi Rahayu Kudus," J. Tek. Elektro, vol. 1, no. 1, pp. 11-21, 2009.

[5] D. O. (Faculty of I. E.-G. U. Maru'ao, "Neural Network Implementation in Foreign Exchange Kurs Prediction," 2010.

[6] A. P. Windarto, P. Studi, and S. Informasi, "Implementasi JST Dalam Menentukan Kelayakan Nasabah Pinjaman KUR Pada Bank Mandiri Mikro Serbelawan Dengan Metode Backpropagation," no. 1, pp. 12-23, 2017. 